\title{
Hydrogeochemical Characterization of Dug Well Water and Its Suitability for Domestic Water Supply in the Village of Passakongo, Dédougou municipality, Burkina Faso
}

\author{
Aboubakar Sako ${ }^{1}$, Sâga Sawadogo ${ }^{2}$, Moïse Yoni ${ }^{1}$, Mamadou Nimi $^{3}$, Ousseni Zongo ${ }^{1} \&$ Ousmane Bamba ${ }^{2}$ \\ ${ }^{1}$ Université de Dédougou, BP 139 Dédougou, Burkina Faso \\ ${ }^{2}$ Université Ouaga 1 Pr Joseph Ki-Zerbo, Département des Sciences de la Terre, 09 BP 848 Ouagadougou 09, \\ Burkina Faso. \\ ${ }^{3}$ Bureau des Mines et de la Géologie du Burkina Faso, Direction Régionale de Bobo- Dioulasso
}

Correspondence: Aboubakar Sako, Université de Dédougou, BP 139 Dédougou, Burkina Faso. E-mail:aboubakar.sako@gmail.com.

Received: August 12, 2018

Accepted: September 1, 2018

Online Published: September 25, 2018

doi:10.5539/enrr.v8n3p126

URL: https://doi.org/10.5539/enrr.v8n3p126

\begin{abstract}
Hydrogeochemical characterization and suitability study of dug well water for domestic purpose were carried out in a semi-arid rural village in Burkina Faso. Thirty water samples were collected from 15 wells in dry and wet seasons, 2017. Electrical conductivity (EC) and total dissolved solids as well as major ions of all samples were within the World Health Organization (WHO) permissible limits for drinking water. In contrast, nine wells had $\mathrm{pH}$ beyond the WHO limit during the dry season and one well had very high $\mathrm{NO}_{3}{ }^{-}$concentration in the wet season. Most wells were seriously polluted with total $\mathrm{Cr}\left(\mathrm{Cr}_{\mathrm{T}}\right)$ in both seasons (11 and 14 wells in dry and wet seasons, respectively). Although $\mathrm{Pb}$ was not detected in the wells during the dry season, six wells showed $\mathrm{Pb}$ concentrations exceeding the WHO guideline limit for drinking water in the wet season. Graphic interpretation, including the Piper diagram, major ion ratios and $\mathrm{Na} / \mathrm{Cl}$ versus $\mathrm{EC}$, were used to characterize the hydrochemistry and water - rock interaction within the wells. The dominant hydrochemical facies of the wells was $\mathrm{Ca}-\mathrm{HCO}_{3}$ during the dry season, reflecting the influence of silicate weathering. Following loadings of agricultural and domestic effluent, the hydrochemical facies shifted to more mixed type during the wet season. All samples had negative chloro-alkaline indices, suggesting retention of $\mathrm{Ca}^{2+}$ and $\mathrm{Mg}^{2+}$ by the aquifer materials and release of $\mathrm{Na}^{+}$and $\mathrm{K}^{+}$into the groundwater. In addition to silicate weathering, the hydrochemistry and water quality of the majority of the wells were partially controlled by the evaporation process and longer water-rock interaction in the dry season. In contrast, recharge and dilution effects appeared to alter the natural hydrochemistry of the wells in the wet season. Geochemical characterization has clearly shown that seasonal changes do affect the dug well water quality. The study also demonstrated that, in terms of $\mathrm{Cr}_{\mathrm{T}}$ and $\mathrm{Pb}$, water from the majority of the wells was not suitable for drinking. A special attention should be therefore paid to groundwater quality protection in the area.
\end{abstract}

Keywords: dug well; hydrochemistry; domestic water supply; semi-arid; rural Burkina Faso

\section{Introduction}

Because of the short wet season and high evapotranspiration, surface water is an unreliable source for domestic water supply in semi-arid regions of Burkina Faso (Groen, 1988; Derouane \& Dakoure, 2006; Courtois et al., 2010; Huneau et al., 2011). Furthermore, surface water requires a considerable investment in terms of storage and purification, whereas construction of a low-technology dug well is much cheaper (Sanou, 1997; Kortatsi, 2007). Consequently, in rural Burkina Faso, shallow hand-dug wells are the main source of domestic water supply (MEE, 2001). The dug well water suitability for drinking depends on its quality, which is governed by a series of natural processes including water-rock interaction, ion exchange and evaporation (Gibbs, 1970; Appelo \& Postma, 2005; Langmuir, 1997; Fetter 1994; Lester \& Birkett, 1999; Li et al., 2016). Inputs from excessive use of agriculture chemical and fertilizers, direct contamination of untreated sewage and mining wastes can also have a profound impact on the dug well water quality (Appelo \& Postma, 1999; Zhang et al., 2011). In rural 
Burkina Faso, like in most parts of Sub-Saharan Africa, people directly drink dug well water without a prior treatment (UN, 2005), thereby increasing risks of waterborne disease outbreak (Wu \& Sun, 2016).

Compared to groundwater availability, groundwater quality has received little attention in Burkina Faso. As a result, little is known about the natural processes that control groundwater composition and the anthropogenic factors that affect its quality. The few available data show that shallow groundwater is exposed to a widespread nutrient and microbial contamination (Groen et al., 1988; Yaméogo \& Savadogo, 2002; Sako et al., 2018). Thus, an assessment of various sources of the pollutants affecting dug well water is central for setting up a robust monitoring plan of drinking water quality. Unfortunately, it is very difficult to identify pollutant sources in the groundwater system based on the field data alone. Several graphical interpretation and evaluation schemes of various ratios and indices have been successfully used to identify sources of pollutants in the groundwater system (e.g., Piper 1944; Schöeller, 1962; Pacheco \& van der Weijden, 1996; Deutsch, 1997; Gaillardet et al., 1999; Zhu et al., 2008). Once the sources of the pollutants are known, the groundwater suitability for domestic supply can be evaluated in accordance with the national or international directives and standards.

Therefore, the objectives of the present study were twofold: to (1) determine the main factors controlling dug well water quality and to (2) evaluate the water suitability for domestic water supply. To achieve these objectives, physico-chemical parameters, major ion and selected heavy metal concentrations were analyzed in 30 dug well samples collected during the dry and wet seasons in a village in northwestern Burkina Faso. The findings of this study are likely to open up new vista for understanding the factors that govern seasonal variability of groundwater quality and to provide decision makers information about the potential uses of dug well water in a rural and semi-arid setting.

\section{Study Area}

The Passakongo village is located in the Dédougou municipality, northwestern Burkina Faso (Figure 1). Geomorphologically, the village is a part of an immense West African peneplain known as the Gondo Plain with altitudes not exceeding $300 \mathrm{~m}$ above sea level (Groen et al., 1988). The area lies within the Sudano-Sahelian (i.e., semi-arid) climatic zone with two distinct seasons (Huneau et al., 2011): a dry season from October to April and a wet season from May to September. The total annual rainfall over the area ranges from 700 to $1020 \mathrm{~mm}$ with an average annual rainfall of $900 \mathrm{~mm}$ (Frappart et al., 2009). The air temperatures vary between 21 to $32^{\circ}$ $\mathrm{C}$ with an average annual temperature of $28^{\circ} \mathrm{C}$. Hence, the potential evapotranspiration of the area is high ( $>2000 \mathrm{~mm} /$ year; Groen et al., 1988). The Mouhoun River is the main watercourse in the area, and around which the hydrographic network is organized. The river is in equilibrium with groundwater levels along the major part of its course. In the last decades, a decrease of about $30 \mathrm{~m}$ in the groundwater level has been observed in the region (Saad, 1970; Huneau et al., 2011). This is strongly correlated with the decrease in the regional rainfall (Dakoure, 2003).

In the study area, the Precambrian sedimentary sequence overlies crystalline bedrock, composed of granite and schist of Birrimien and Antebirrimien ages (Sattran \& Wenmenga, 2002). The lithology of the sedimentary rocks is dominated by sandstones, schist and dolomite (Figure 1) (Ouédraogo, 1998; Castaing et al., 2003). The deep joined sandstone and the shallow weathered overburden aquifers are the two types of aquifers that occur in the area (Groen et al., 1988). These aquifers are part of the southeastern Taoudeni Basin Aquifer shared by Mali and Burkina Faso, and constitute the only source of drinking water in Dédougou and its surrounding areas. In the town of Dédougou, domestic water supply is mainly derived from the deep joined sedimentary aquifer through private boreholes and tap water supplied by the public water supply system, whereas in rural areas, including the study area, water for human consumption is abstracted from the weathered overburden aquifer through unprotected large diameter (up to $1.5 \mathrm{~m}$ ) dug wells. The village of Passakongo has an estimated population of 6,290 people consisting mainly of farmers. Because of the high population densities and intensive agricultural practices in the area, the local groundwater is prone to high contamination from agricultural runoff and domestic wastewater.

\section{Materials and Methods}

A total of 30 water samples were randomly collected from 15 hand-dug wells in the village of Passakongo during dry and wet seasons, 2017 (Figure 2). In order to minimize cross contaminations, a sterilized plastic bucket was used to draw water samples. The samples were subsequently filtered through $0.45 \mu \mathrm{m}$ Millipore membranes into two sets of high density polyethylene bottles. To avoid cation precipitation and their adsorption onto the container, one set of the samples was immediately acidified $(\mathrm{pH}<2)$ with ultrapure nitric acid, whereas the other set was left unacidified. Physico-chemical parameters such as $\mathrm{pH}$, electrical conductivity (EC) and total 
dissolved solids (TDS) were measured in the field using calibrated meters. All the samples were stored at $-4^{\circ} \mathrm{C}$ and taken to the laboratory for major ion and heavy metal analyses.

Sulfate $\left(\mathrm{SO}_{4}{ }^{2-}\right)$, nitrate $\left(\mathrm{NO}_{3}^{-}\right)$, ammonium $\left(\mathrm{NH}_{4}{ }^{+}\right)$and phosphate $\left(\mathrm{PO}_{4}{ }^{3-}\right)$ concentrations of unacidified samples were determined using UV-visible spectrometry technique, whereas the Mohr method was used to determine chloride concentrations by titration with silver nitrate $\left(\mathrm{AgNO}_{3}\right)$ and potassium chromate as an indicator (American Public Health Association, 2012). Volumetric method was used to measure bicarbonate $\left(\mathrm{HCO}_{3}{ }^{-}\right.$) and total hardness (TH). Concentrations of major cations $\left(\mathrm{Ca}^{2+}, \mathrm{Mg}^{2+}, \mathrm{K}^{+}\right.$and $\left.\mathrm{Na}^{+}\right)$and heavy metals $\left(\mathrm{Fe}_{\mathrm{T}}, \mathrm{Cr}_{\mathrm{T}}\right.$ and $\mathrm{Pb}$ ) in acidified samples were determined using an atomic absorption spectrometer (Perkin Elmer Analyst 100). For the investigated cations, the sum of blanks from filters and reagents was always less than $10 \%$ of the analyte concentrations.

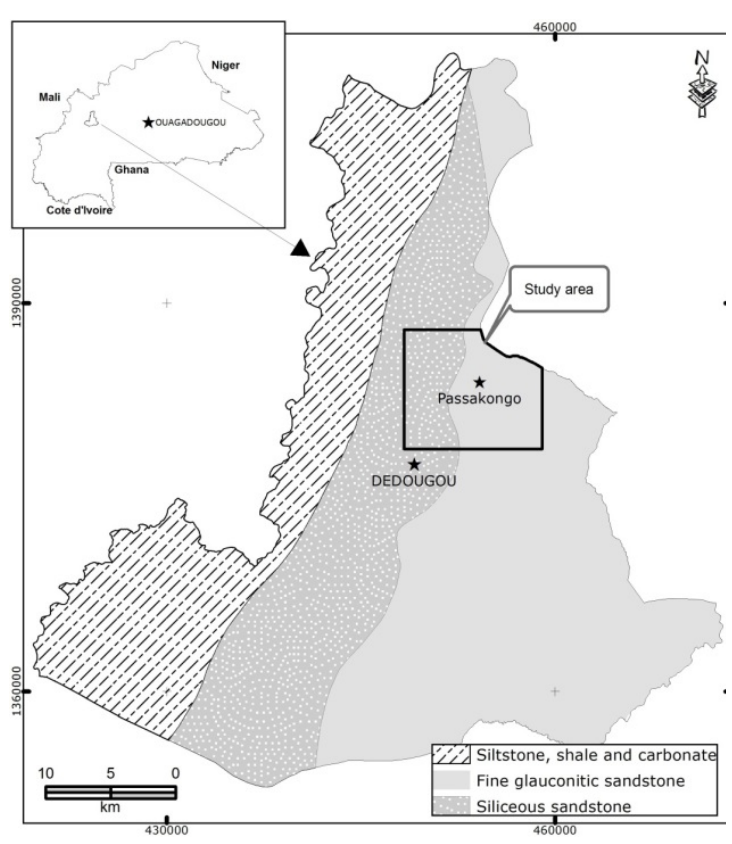

Figure 1. Regional geological map, showing the study area

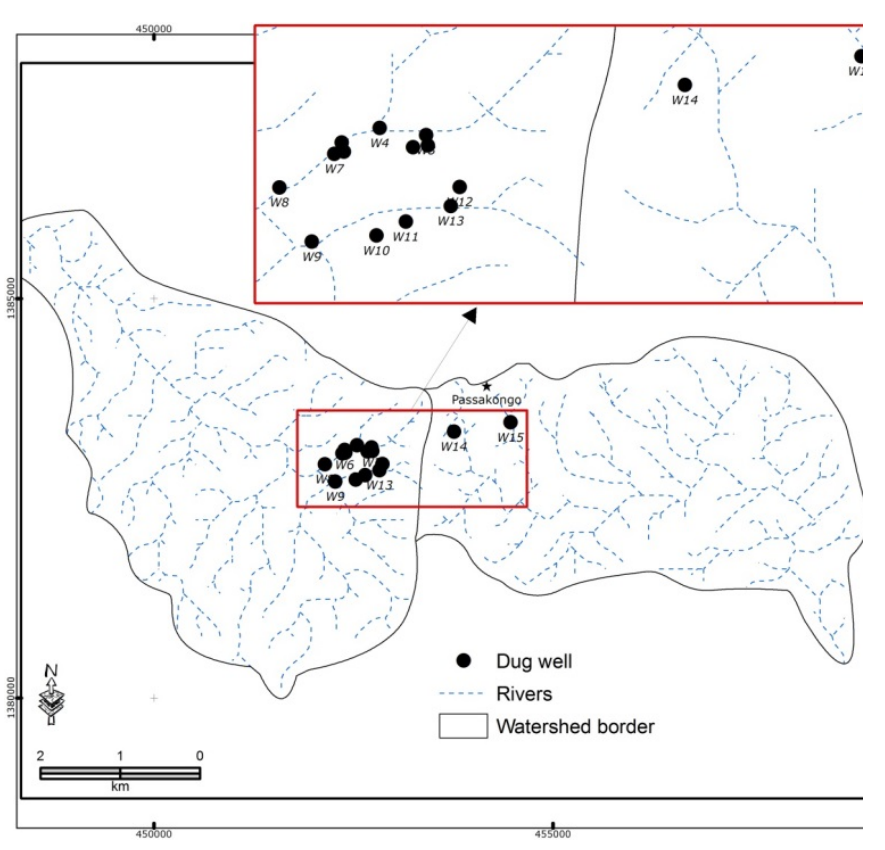

Figure 2. Dug well water sampling points

\section{Results and Discussion}

\subsection{Dug Well Water Quality for Domestic Purpose}

The abundance of hydrogeochemical parameters in dug well waters varied broadly among wells and between seasons (Table 1). With $\mathrm{pH}$ ranging from 4.6 to 6.4 (average $\pm \mathrm{SD}=5.8 \pm 0.5$ ), dug well water was acidic in the dry season and slightly acidic to alkaline in the wet season $(\mathrm{pH}=6.12-7.6$; average $=7)$. Comparing to the WHO guideline, nine wells had pH beyond the permissible limit for drinking water in the dry season (Table 2). The acidic nature may also enhance mobility and bioavailability of certain potentially harmful metals in the wells. The slightly alkaline nature of the dug well water in the wet season could be attributed to high loadings of $\mathrm{HCO}_{3}{ }^{-}$and alkaline earth elements from agricultural sources and chemical weathering within the catchment. All the EC and TDS values in the wells in both seasons were within the safe limits for drinking water compared with the WHO guideline values. Electrical conductivity measures the degree of salinity in water, which greatly affects the taste. The low EC in the present wells is an indication of low mineralization (Boeglin et al., 2003; Braun et al., 2005) encountered in the weathered mantle aquifers. The major contribution to TDS in water is the waterrock interaction with a minor contribution from pollution (John De Zuane, 1997). The relatively high values of EC and TDS in the wells in the dry season reflect the influence of evaporation and extended water-rock interaction between the well water and the aquifer minerals. Although the average TH did not show any seasonal variations (average $\pm \mathrm{SD}=54.4 \pm 30$ and $54 \pm 45 \mathrm{mg} \mathrm{CaCO} / \mathrm{L}$, respectively), its concentration in the wet season was more sporadic with a high coefficient of variance $(\mathrm{CV}=84 \%)$ compared to that of the dry season $(\mathrm{CV}=$ 
55\%). This suggests that in addition to water-rock interaction, ionic concentrations in the wells during the wet season may be due to the aquifer recharge.

Table 1. Hydrogeochemical parameters of dug well samples from the Passakongo village. All parameters are expressed in $\mathrm{mg} / \mathrm{L}$ except electrical conductivity (EC in $\mu \mathrm{S} / \mathrm{cm}$ )

\begin{tabular}{|c|c|c|c|c|c|c|c|c|c|c|c|c|c|c|c|c|c|c|c|}
\hline Well No & Season & $\mathrm{EC}$ & $\mathrm{pH}$ & TDS & TH & $\mathrm{HCO}_{3}^{-}$ & $\mathrm{K}^{+}$ & $\mathrm{Na}^{+}$ & $\mathrm{Ca}^{2+}$ & $\mathrm{Mg}^{2+}$ & $\mathrm{Cl}^{-}$ & $\mathrm{NO}_{3}^{-}$ & $\mathrm{NH}_{4}^{+}$ & $\mathrm{NO}_{2}{ }^{-}$ & $\mathrm{PO}_{4}^{3-}$ & $\mathrm{SO}_{4}{ }^{2-}$ & $\mathrm{Fe}_{\mathrm{T}}$ & $\mathrm{Cr}_{\mathrm{T}}$ & $\mathrm{Pb}$ \\
\hline \multirow[t]{2}{*}{1} & Dry & 442 & 6.4 & 275 & 128 & 62.2 & 73.3 & 7.7 & 49.7 & 1.0 & 10.0 & 9.8 & 0.0 & 0.6 & 0.6 & 22.5 & 0.00 & 0.00 & 0.00 \\
\hline & Wet & 634 & 7.4 & 208 & 216 & 68.3 & 29.2 & 6.2 & 30.5 & 2.9 & 11.5 & 0.0 & 0.0 & 0.1 & 0.2 & 86.6 & 0.45 & 0.42 & 0.00 \\
\hline \multirow[t]{2}{*}{2} & Dry & 165 & 5.9 & 149 & 24 & 25.6 & 19.0 & 2.8 & 24.1 & 0.0 & 2.5 & 11.9 & 2.3 & 0.1 & 0.2 & 0.3 & 0.42 & 0.56 & 0.00 \\
\hline & Wet & 190 & 7.6 & 116 & 52 & 29.3 & 60.4 & 5.6 & 12.8 & 1.0 & 2.5 & 0.0 & 0.8 & 0.0 & 0.2 & 11.3 & 0.46 & 0.33 & 0.00 \\
\hline \multirow[t]{2}{*}{3} & Dry & 77 & 5.8 & 67 & 44 & 22.0 & 14.7 & 3.4 & 19.2 & 0.0 & 5.5 & 6.3 & 0.0 & 0.1 & 0.3 & 51.0 & 0.49 & 0.00 & 0.00 \\
\hline & Wet & 105 & 7.6 & 84 & 32 & 23.2 & 24.8 & 4.5 & 8.0 & 6.8 & 3.0 & 0.0 & 0.0 & 0.1 & 0.2 & 0.0 & 0.38 & 0.45 & 0.00 \\
\hline \multirow[t]{2}{*}{4} & Dry & 188 & 5.9 & 139 & 68 & 40.3 & 4.9 & 6.3 & 17.6 & 5.8 & 5.0 & 10.9 & 0.0 & 0.1 & 0.1 & 5.8 & 0.00 & 0.00 & 0.00 \\
\hline & Wet & 163 & 7.4 & 123 & 52 & 31.7 & 25.2 & 4.8 & 12.0 & 6.3 & 5.0 & 0.0 & 0.0 & 0.0 & 0.0 & 10.3 & 0.00 & 0.35 & 0.00 \\
\hline \multirow[t]{2}{*}{5} & Dry & 231 & 6.1 & 167 & 24 & 32.9 & 19.3 & 4.7 & 30.5 & 0.0 & 5.0 & 11.6 & 0.0 & 0.0 & 0.2 & 4.5 & 0.11 & 2.85 & 0.00 \\
\hline & Wet & 541 & 7.1 & 236 & 40 & 187.9 & 18.3 & 10.6 & 28.9 & 0.0 & 15.5 & 3.5 & 0.0 & 0.0 & 0.0 & 43.6 & 0.34 & 0.60 & 0.08 \\
\hline \multirow[t]{2}{*}{6} & Dry & 139 & 6.1 & 115 & 44 & 30.5 & 9.7 & 2.2 & 17.6 & 0.0 & 2.5 & 1.7 & 1.7 & 0.0 & 0.3 & 8.3 & 0.74 & 0.00 & 0.00 \\
\hline & Wet & 226 & 7.4 & 130 & 44 & 65.9 & 224.1 & 5.5 & 16.0 & 2.9 & 5.0 & 8.4 & 0.0 & 0.0 & 0.1 & 10.9 & 0.25 & 0.30 & 0.14 \\
\hline \multirow[t]{2}{*}{7} & Dry & 336 & 6.4 & 209 & 56 & 54.9 & 26.5 & 6.7 & 49.7 & 0.0 & 7.5 & 11.9 & 0.0 & 0.1 & 0.1 & 10.7 & 0.34 & 7.87 & 0.00 \\
\hline & Wet & 521 & 7.1 & 295 & 36 & 102.5 & 200.7 & 10.5 & 44.9 & 0.0 & 15.5 & 13.4 & 0.0 & 0.0 & 0.0 & 45.4 & 0.00 & 0.13 & 0.26 \\
\hline \multirow[t]{2}{*}{8} & Dry & 357 & 6.4 & 229 & 72 & 70.8 & 46.7 & 7.3 & 44.9 & 0.0 & 10.5 & 11.9 & 0.0 & 0.1 & 0.0 & 6.2 & 0.44 & 4.86 & 0.00 \\
\hline & Wet & 458 & 7.2 & 250 & 36 & 26.8 & 65.8 & 10.1 & 33.7 & 0.0 & 12.5 & 8.9 & 0.0 & 0.0 & 0.0 & 30.0 & 0.00 & 0.31 & 0.26 \\
\hline \multirow[t]{2}{*}{9} & Dry & 258 & 6.3 & 177 & 100 & 57.3 & 39.3 & 7.9 & 28.9 & 6.8 & 7.5 & 11.5 & 1.7 & 0.1 & 0.4 & 11.2 & 0.03 & 3.29 & 0.00 \\
\hline & Wet & 362 & 7.1 & 239 & 40 & 70.8 & 69.5 & 10.8 & 24.1 & 0.0 & 10.0 & 0.0 & 0.0 & 0.0 & 0.0 & 21.6 & 0.00 & 0.44 & 0.39 \\
\hline \multirow[t]{2}{*}{10} & Dry & 215 & 5.5 & 142 & 72 & 23.2 & 15.9 & 4.5 & 24.1 & 2.9 & 5.0 & 11.7 & 0.0 & 0.0 & 0.0 & 5.6 & 0.00 & 0.31 & 0.00 \\
\hline & Wet & 247 & 6.9 & 148 & 52 & 35.4 & 24.4 & 6.0 & 15.2 & 2.4 & 7.5 & 9.1 & 0.0 & 0.0 & 0.0 & 6.7 & 0.03 & 0.25 & 0.35 \\
\hline \multirow[t]{2}{*}{11} & Dry & 187 & 5.2 & 130 & 40 & 14.6 & 18.4 & 5.9 & 27.3 & 0.0 & 3.0 & 12.1 & 0.7 & 0.1 & 0.2 & 1.0 & 0.00 & 2.55 & 0.00 \\
\hline & Wet & 196 & 6.9 & 120 & 28 & 11.0 & 21.5 & 6.2 & 12.0 & 14.1 & 2.5 & 8.0 & 0.0 & 0.0 & 0.0 & 0.0 & 0.00 & 0.23 & 0.00 \\
\hline \multirow[t]{2}{*}{12} & Dry & 212 & 5.8 & 138 & 52 & 11.0 & 46.5 & 4.5 & 14.4 & 3.9 & 6.0 & 9.4 & 0.0 & 0.0 & 0.3 & 17.8 & 0.00 & 1.75 & 0.00 \\
\hline & Wet & 256 & 6.8 & 139 & 40 & 35.4 & 39.7 & 4.7 & 10.4 & 6.3 & 5.0 & 8.0 & 0.0 & 0.0 & 0.1 & 22.0 & 0.22 & 0.37 & 0.00 \\
\hline \multirow[t]{2}{*}{13} & Dry & 87 & 5.0 & 73 & 36 & 37.8 & 8.3 & 6.2 & 12.8 & 1.0 & 6.0 & 8.1 & 1.6 & 0.1 & 0.1 & 1.7 & 0.00 & 0.00 & 0.00 \\
\hline & Wet & 99 & 6.9 & 78 & 52 & 8.5 & 13.3 & 4.8 & 5.6 & 5.3 & 1.5 & 66.3 & 0.0 & 0.0 & 0.0 & 0.0 & 0.21 & 0.35 & 0.00 \\
\hline \multirow[t]{2}{*}{14} & Dry & 130 & 4.6 & 111 & 28 & 12.2 & 8.1 & 11.1 & 16.0 & 0.0 & 5.5 & 11.3 & 2.1 & 0.0 & 0.1 & 0.0 & 0.00 & 7.05 & 0.00 \\
\hline & Wet & 132 & 6.2 & 116 & 44 & 6.1 & 13.3 & 12.9 & 5.6 & 2.4 & 3.5 & 8.1 & 0.0 & 0.0 & 0.0 & 0.0 & 0.00 & 0.45 & 0.00 \\
\hline \multirow[t]{2}{*}{15} & Dry & 22 & 5.7 & 26 & 28 & 29.3 & 1.2 & 1.9 & 6.4 & 2.9 & 4.0 & 0.9 & 0.8 & 0.0 & 0.0 & 0.0 & 0.50 & 2.87 & 0.00 \\
\hline & Wet & 25 & 6.5 & 11 & 44 & 13.4 & 0.0 & 2.6 & 1.0 & 0.0 & 2.0 & 0.1 & 0.3 & 0.0 & 0.0 & 0.0 & 0.00 & 0.00 & 0.00 \\
\hline
\end{tabular}

The order of major cation concentrations in the wells during the dry season was: $\mathrm{Ca}^{2+}>\mathrm{K}^{+}>\mathrm{Na}^{+}>\mathrm{Mg}^{2+}$, whereas that of the wet season was: $\mathrm{K}^{+}>\mathrm{Ca}^{2+}>\mathrm{Na}^{+}>\mathrm{Mg}^{2+}$. In contrast, major anion concentrations showed an identical seasonal distribution $\left(\mathrm{HCO}_{3}>\mathrm{SO}_{4}{ }^{2-}>\mathrm{NO}_{3}{ }^{-}>\mathrm{Cl}^{-}>\mathrm{PO}_{4}{ }^{3-}\right.$ ) with higher average concentrations of $\mathrm{HCO}_{3}{ }^{-}, \mathrm{SO}_{4}{ }^{2-}$ and $\mathrm{Cl}^{-}$in the wet season relative to the dry season, reflecting inputs from agricultural runoff and domestic effluent (Figure 3). The observed similarity in the ion distribution pattern indicates that dug well water flow within the aquifer is similar in both seasons. Concentrations of $\mathrm{Na}^{+}, \mathrm{Ca}^{2+}, \mathrm{Mg}^{2+}, \mathrm{K}^{+}, \mathrm{HCO}_{3}{ }^{-}$and $\mathrm{SO}_{4}{ }^{2-}$ were within the recommended values for drinking water (WHO, 2011). However, it can be noted that all samples (except well 15) had $\mathrm{K}^{+}$concentrations largely above the European Economic Community (EEC, 1980) guideline value of 10 $\mathrm{mg} / \mathrm{L}$ during the wet season and $67 \%$ of the samples in the dry season. The main sources of $\mathrm{K}^{+}$in groundwater include rain water, weathering of orthoclase and clay minerals and the use of fertilizers (Rail, 2000). According to Rail (2000), $\mathrm{K}^{+}$concentrations in groundwater up to $10 \mathrm{mg} / \mathrm{L}$ are attributed to orthoclase or clay weathering, whereas concentrations above $10 \mathrm{mg} / \mathrm{L}$ may indicate external sources. Therefore, it can be concluded that $\mathrm{K}^{+}$ concentrations in the majority of the dug well is derived from external sources (i.e., fertilizers). Only well14 had $\mathrm{NO}_{3}{ }^{-}$concentration exceeding the WHO recommended value for drinking water during the wet season. Furthermore, 13 wells had $\mathrm{NO}_{3}^{-}$concentrations in the dry season exceeding the natural nitrate background concentrations (5- $7 \mathrm{mg} / \mathrm{L}$; Appelo and Postma, 1999) against 8 wells in the wet season (Table 2). The relatively high $\mathrm{NO}_{3}{ }^{-}$content in the dug wells in the dry season could be related to a longer residence time of the groundwater compared to a high mixing rate during the wet season. Boxplots showed high variability in $\mathrm{HCO}_{3}$, $\mathrm{Cl}^{-}, \mathrm{Ca}^{2+}, \mathrm{Na}^{+}$and $\mathrm{Mg}^{2+}$ abundance in the wet season (Figure 4), suggesting high external loadings of these ions in the groundwater system through runoff. The relatively heterogeneous distribution of EC in the wet season, as highlighted by coefficient of variance $(\mathrm{CV}=66 \%)$ and boxplot (Figure 4), is a clear indication of the substantial contribution of $\mathrm{HCO}_{3}^{-}, \mathrm{Cl}^{-}, \mathrm{Ca}^{2+}, \mathrm{Na}^{+}$and $\mathrm{Mg}^{2+}$ to the total ionic composition of the well water during this season. 


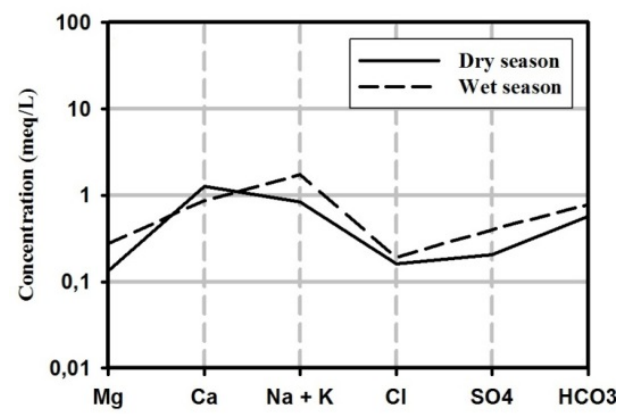

Figure 3. Schöeller-Berkaloff diagram showing dug well water classification the dug well water (Schöller, 1962) based on the average seasonal concentrations of the ions
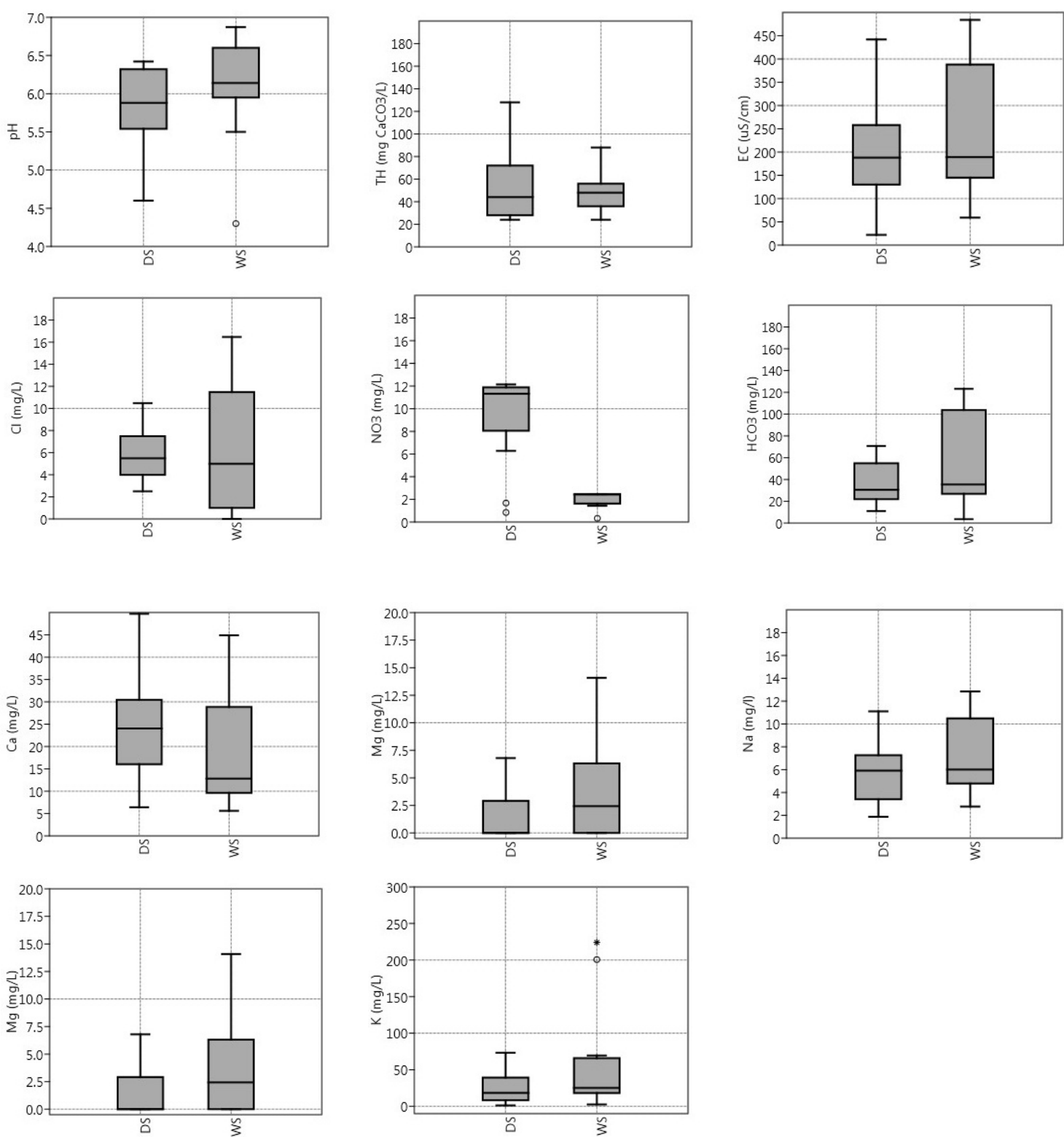

Figure 4. Boxplots depicting seasonal variations of selected physico-chemical parameters of dug well samples. The tops and bottoms of the boxes represent the $75^{\text {th }}$ and $25^{\text {th }}$ percentiles, respectively. The horizontal line across the boxes indicates the median. The vertical lines from the tops and bottoms of the boxes extend to $90^{\text {th }}$ and $10^{\text {th }}$ percentiles, respectively. DS: dry season and WS: wet season 
Total iron $\left(\mathrm{Fe}_{\mathrm{T}}\right)$ concentrations varied from 0.00 to $0.74 \mathrm{mg} / \mathrm{L}$ with average concentrations of $0.2 \pm 0.25$ and $0.16 \pm 0.2 \mathrm{mg} / \mathrm{L}$ in dry and wet seasons, respectively (Table 2). Five wells (Wells 2, 3, 6, 7 and 15) had $\mathrm{Fe}_{\mathrm{T}}$ concentrations greater than the WHO guideline values $(0.3 \mathrm{mg} / \mathrm{L})$ and almost the same wells in the wet seasons (Wells, 1,2,3,5 and 6). Fourteen (except well 15) and 11 wells had $\mathrm{Cr}_{\mathrm{T}}$ concentrations exceeding the WHO guideline value for drinking water $(0.05 \mathrm{mg} / \mathrm{L})$ in wet and dry seasons, respectively. Total chromium concentrations in groundwater can be ascribed to weathering of ultramafic rocks and serpentinites of ophiolite complexes (Oze et al., 2004) or to anthropogenic sources such as industrial activities and application of numerous biosolids (Wuana \& Okieimen, 2011). In the Passakongo village, beside agriculture and animal husbandry, there are no industrial activities to serve as point source for $\mathrm{Cr}_{\mathrm{T}}$, and thus the main source of $\mathrm{Cr}_{\mathrm{T}}$ in the wells appeared to be agricultural practices and, to a lesser extent, chemical weathering. Although $\mathrm{Pb}$ was not measured in the wells during the dry season, six wells (Wells 5, 6, 7, 8, 9 and 10) had Pb concentrations greater than the WHO guideline value $(0.01 \mathrm{mg} / \mathrm{L})$ in the wet season. It can be concluded that agricultural runoff and domestic effluent exert negative impacts on the dug well water quality.

Table 2. Summary statistics of hydrogeochemical parameters of dug well samples and their comparison with the WHO standards for drinking water

\begin{tabular}{|c|c|c|c|c|c|c|c|c|c|c|c|c|}
\hline \multirow[t]{3}{*}{ Parameter } & \multicolumn{9}{|c|}{ Descriptive statistics } & \multicolumn{3}{|c|}{ Acceptable limits (WHO, 2011) Sample numbers exceeding acceptable limit values } \\
\hline & \multicolumn{5}{|c|}{ Dry season } & \multicolumn{4}{|c|}{ Wet season } & & \multirow[t]{2}{*}{ Dry season } & \multirow[t]{2}{*}{ Wet season } \\
\hline & Unit & Min & Max & Mean & Std & Min & Max & Mean & Std & & & \\
\hline $\mathrm{EC}$ & $\mu \mathrm{S} / \mathrm{Cm}$ & 22 & 442 & 203 & 112 & 25 & 634 & 277 & 183,9 & 750 & None & None \\
\hline $\mathrm{pH}$ & & 4.6 & 6.4 & 5.8 & 0.5 & 6.2 & 7.6 & 7.0 & 0.0 & $6.5-9.2$ & $2,3,4,10,11,12,13,14,15$ & None \\
\hline TDS & $\mathrm{mg} / \mathrm{L}$ & 26 & 275 & 143 & 64 & 11 & 294,6 & 153 & 77 & 500 & None & None \\
\hline $\mathrm{TH}$ & $\mathrm{mg} / \mathrm{L}$ & 24 & 128 & 54.4 & 30 & 28 & 216 & 54 & 45 & 100 & 1 & 1 \\
\hline $\mathrm{HCO}_{3}^{-}$ & $\mathrm{mg} / \mathrm{L}$ & 11.0 & 70.8 & 35.0 & 18.7 & 6.1 & 187.9 & 47.7 & 47.6 & 200 & None & None \\
\hline $\mathrm{K}^{+}$ & $\mathrm{mg} / \mathrm{L}$ & 1.2 & 73.3 & 23.4 & 19.8 & 0.0 & 224.1 & 55.3 & 67.0 & 100 & None & 6,7 \\
\hline $\mathrm{Na}^{+}$ & $\mathrm{mg} / \mathrm{L}$ & 1.9 & 11.1 & 5.5 & 2.5 & 2.5 & 12.8 & 7.0 & 3.1 & 200 & None & None \\
\hline $\mathrm{Ca}^{2+}$ & $\mathrm{mg} / \mathrm{L}$ & 6.4 & 49.7 & 25.5 & 13.3 & 1.0 & 44.9 & 17.4 & 12.4 & 200 & None & None \\
\hline $\mathrm{Mg}^{2+}$ & $\mathrm{mg} / \mathrm{L}$ & 0.0 & 6.8 & 1.6 & 2.3 & 0.0 & 14.1 & 3.4 & 3.9 & 150 & None & None \\
\hline $\mathrm{Cl}^{-}$ & $\mathrm{mg} / \mathrm{L}$ & 2.5 & 10.5 & 5.7 & 2.4 & 1.5 & 15.47 & 6.8 & 4.9 & 250 & None & None \\
\hline $\mathrm{NO}_{3}^{-}$ & $\mathrm{mg} / \mathrm{L}$ & 0.9 & 12.1 & 9.4 & 3.7 & 0.0 & 66.3 & 8.9 & 16.5 & 50 & None & 13 \\
\hline $\mathrm{NH}_{4}^{+}$ & $\mathrm{mg} / \mathrm{L}$ & 0.0 & 2.3 & 0.7 & 0.9 & 0.0 & 0.8 & 0.1 & 0.2 & & None & None \\
\hline $\mathrm{NO}_{2}^{-}$ & $\mathrm{mg} / \mathrm{L}$ & 0.0 & 0.6 & 0.1 & 0.2 & 0.0 & 0.1 & 0.0 & 0.0 & & None & None \\
\hline $\mathrm{PO}_{4}{ }^{3-}$ & $\mathrm{mg} / \mathrm{L}$ & 0.0 & 0.6 & 0.2 & 0.2 & 0.0 & 0.2 & 0.1 & 0.1 & & None & None \\
\hline $\mathrm{SO}_{4}{ }^{2-}$ & $\mathrm{mg} / \mathrm{L}$ & 0.0 & 51.0 & 9.8 & 13.2 & 0.0 & 86.6 & 19.2 & 24.1 & 250 & None & None \\
\hline $\mathrm{Fe}_{\mathrm{T}}$ & $\mathrm{mg} / \mathrm{L}$ & 0.00 & 0.74 & 0.20 & 0.25 & 0.00 & 0.46 & 0.16 & 0,20 & 0,3 & $2,3,6,7,15$ & $1,2,3,5,6$ \\
\hline $\mathrm{Cr}_{\mathrm{T}}$ & $\mathrm{mg} / \mathrm{L}$ & 0.00 & 7.87 & 2.26 & 2.61 & 0.00 & 0.60 & 0.33 & 0.10 & 0,05 & $2,5,7,8,9,10,11,12,14,15$ & $1,2,3,4,5,6,7,8,9,10,11,12,13,14$ \\
\hline $\mathrm{Pb}$ & $\mathrm{mg} / \mathrm{L}$ & 0.00 & 0.00 & 0.00 & 0.00 & 0.00 & 0.39 & 0.10 & 0.10 & 0,01 & None & $5,6,7,8,9,10$ \\
\hline
\end{tabular}

The pollution load in dug wells was evaluated using the pollution index proposed by Pacheco and Van der Weijden (1996) and Soumya et al. (2013). According to these authors, pollution effect can be quantified as percentage of $\mathrm{Cl}^{-}, \mathrm{SO}_{4}{ }^{2-}, \mathrm{NO}_{3}{ }^{-}, \mathrm{HCO}_{3}{ }^{-}$and $\mathrm{CO}_{3}{ }^{2-}$ concentrations in groundwater expressed in meq/L. Chloride, $\mathrm{HCO}_{3}{ }^{-}$and $\mathrm{CO}_{3}{ }^{2-}$ are assumed to derive from natural processes, whereas $\mathrm{NO}_{3}{ }^{-}$and $\mathrm{SO}_{4}{ }^{2-}$ are mainly originated from agricultural sources (Soumya et al., 2013). The percentage of pollution index (PI) for individual wells was calculated as follows (Eq. 1):

$$
\% \text { Pollution }=\frac{\left[\mathrm{Cl}^{-}\right]+\left[\mathrm{SO}_{4}^{2-}\right]+\left[\mathrm{NO}_{3}^{-}\right]}{\left[\mathrm{Cl}^{-}\right]+\left[\mathrm{SO}_{4}^{2-}\right]+\left[\mathrm{NO}_{3}^{-}\right]+\text {Alkalinity }} 100
$$

Where alkalinity $=\left[\mathrm{HCO}_{3}^{-}\right]+\left[\mathrm{CO}_{3}{ }^{2-}\right]$

Based on the calculated pollution indices, wells $1,8,11,13$ and 14 were highly polluted with PI greater than $40 \%$ during the wet season (Figure 5a). In contrast, only wells 3, 12 and, to a lesser degree, 10 and 11 had $\mathrm{PI}>40 \%$ in the dry season. Furthermore, the contribution of chemical weathering and pollution to the dug well chemistry was assessed using the scatter plot of $\mathrm{Na} / \mathrm{Cl}$ ratios versus percentage pollution indices of the wells (Soumya et al., 2013). The wells with $\mathrm{PI}<40 \%$ are dominated by chemical weathering, whereas those having PI $>40 \%$ are dominated by pollution (Pacheco and Van der Weijden, 1996). According to the PI values, the 
majority of the wells was highly influenced by anthropogenic inputs during both seasons compared to chemical weathering (Figure 5b).
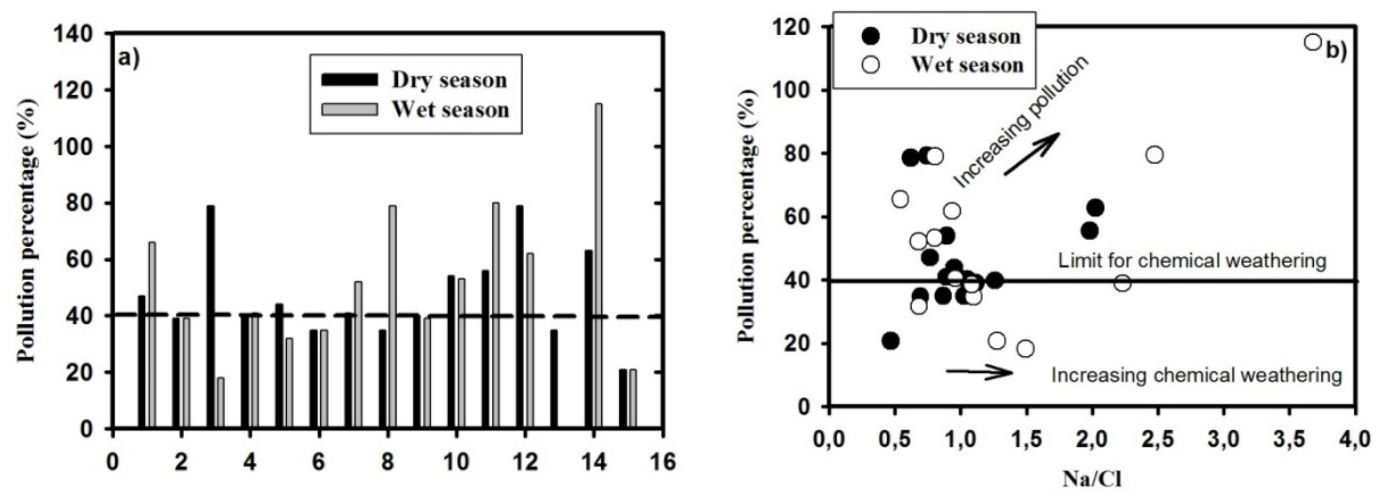

Figure 5. a) Seasonal pollution percentage of the 15 dug well water samples (well No 13 with a very high PI value was excluded) from the Passakongo. b) Variation of pollution percentage versus $\mathrm{Na} / \mathrm{Cl}$ (Soumya et al., 2013)

\subsection{Hydrogeochemical Evolution of Dug Well Water}

Factors such as seasonal and temporal variations, lithology, environmental factors, recharge quality, flow patterns and weathering are likely to change the ionic composition of groundwater. Traditionally, the Piper diagram has been used to study the similarities and differences in the composition of waters and to classify them to hydrochemical facies (Piper, 1944; Sadashivaiah et al. 2008; Utom et al. 2013). The term hydrochemical facies is used to describe groundwaters in an aquifer with varying chemical composition. In the present study, the Piper diagram of the seasonal distribution of major ions revealed four distinct water facies in the Passakongo's dug wells (Figure 6). Thirteen water samples were classified as $\mathrm{Ca}-\mathrm{HCO}_{3}$ type and one sample as mixed $\mathrm{Ca}-\mathrm{Mg}-\mathrm{Cl}$ and another sample as $\mathrm{Na}-\mathrm{Cl}$ type during the dry season, reflecting the predominant influence of water -rock interaction on the hydrogeochemical signature of the well water (Smedley et al., 2007; Mall et al., 2015; Sako et al., 2016; Rakotondrabe et al., 2017). The hydrochemical facies shifted from predominately Ca $-\mathrm{HCO}_{3}$ type to mixed $\mathrm{Ca}-\mathrm{Na}-\mathrm{HCO}_{3}\left(2\right.$ well), $\mathrm{Na}-\mathrm{HCO}_{3}$ ( 5 wells), $\mathrm{Ca}-\mathrm{Mg}-\mathrm{Cl}(2$ wells), $\mathrm{Ca}-\mathrm{Cl}$ ( 1 well) and $\mathrm{Na}-\mathrm{Cl}$ (1 well) types during the wet period. This is an indication of agricultural return flow and ion exchange processes.

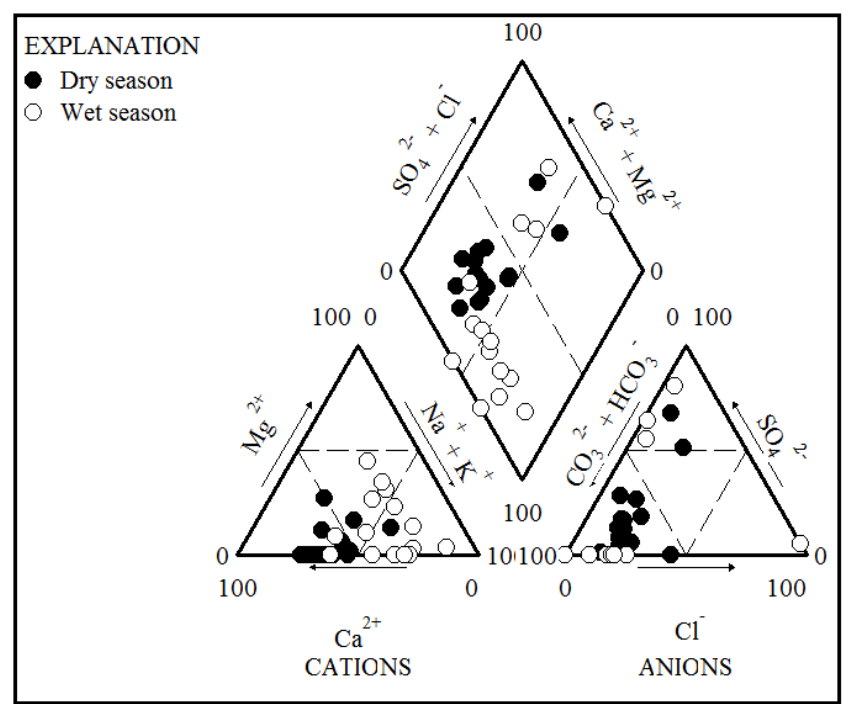

Figure 6. Piper diagram representing hydrochemical facies of dug well water during dry and wet seasons

(Piper, 1944) 
The chloro-alkaline (CAI-1 and CAI-2) indices developed by Schöeller (1965), were used to evaluate a possible ion exchange between the dug well waters and the aquifer minerals (Eq.2 -3$)$.

$$
\begin{gathered}
\mathrm{CAI}-1=\frac{\left(\mathrm{Cl}^{-}-\left(\mathrm{Na}^{+}+\mathrm{K}^{+}\right)\right.}{\mathrm{Cl}^{-}} \\
\mathrm{CAI}-2=\frac{\left(\mathrm{Cl}^{-}-\left(\mathrm{Na}^{+}+\mathrm{K}^{+}\right)\right.}{\left(\mathrm{SO}_{4}^{2-}+\mathrm{HCO}_{3}^{-}+\mathrm{CO}_{3}^{2-}+\mathrm{NO}_{3}^{-}\right)}
\end{gathered}
$$

If both indices are negative, $\mathrm{Ca}^{2+}$ and $\mathrm{Mg}^{2+}$ have been adsorbed onto the aquifer materials and $\mathrm{Na}^{+}$and $/$or $\mathrm{K}^{+}$ have been release into solution. If the indices are positive, then the inverse reactions have taken place. In the present study, the two indices were negative for all samples (Figure 7), suggesting that reverse ion exchange has contributed to $\mathrm{Na}^{+}$and $\mathrm{K}^{+}$abundance and reduction of $\mathrm{Ca}^{2+}$ and $\mathrm{Mg}^{2+}$ concentrations in the wells.
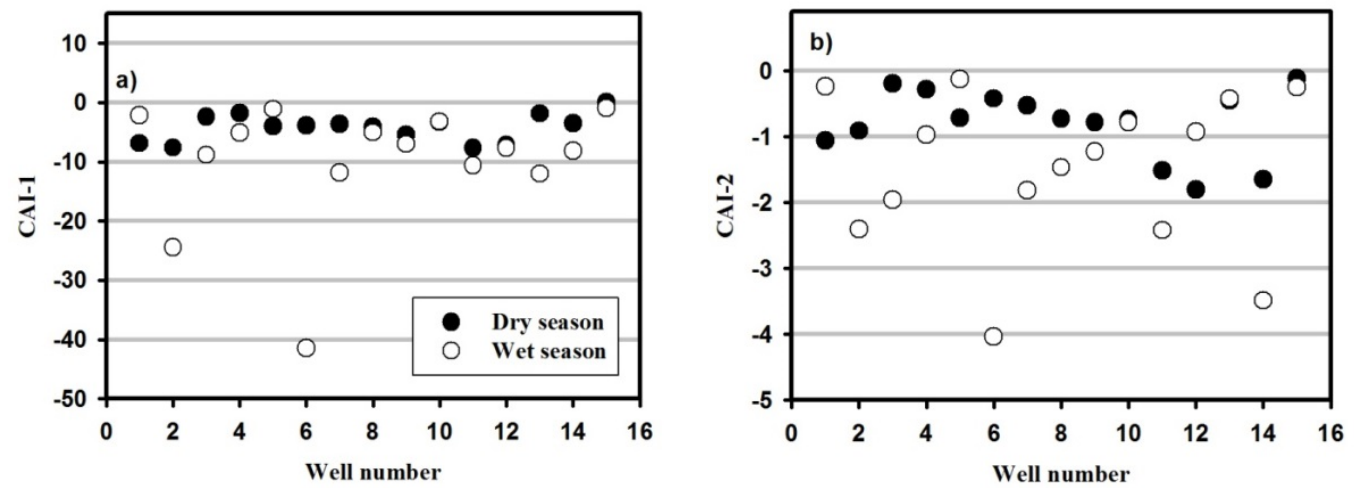

Figure 7. Chloro-alkaline indices showing ion exchange processes in dug well water in both dry and wet season

The influence of weathering on the dug well water hydrochemistry was assessed using the bivariate mixing plots of $\mathrm{Na}^{+}$- normalized $\mathrm{Ca}^{2+}$ versus $\mathrm{Na}^{+}$- normalized $\mathrm{HCO}_{3}{ }^{-}$(Figure $8 \mathrm{a}$ ) and $\mathrm{Na}^{+}$-normalized $\mathrm{Mg}^{2+}$ (Figure $8 \mathrm{~b}$ ) on log-log scale (Gaillardet et al., 1999). Dry season samples (except 2 wells) clustered around the silicate end-member, indicating the influence of silicate weathering on the dug well water's hydrochemistry. In contrast, the wet season samples spread around the silicate end-member, implying that in addition to silicate weathering, anthropogenic activities could contribute to the wells' hydrochemistry.
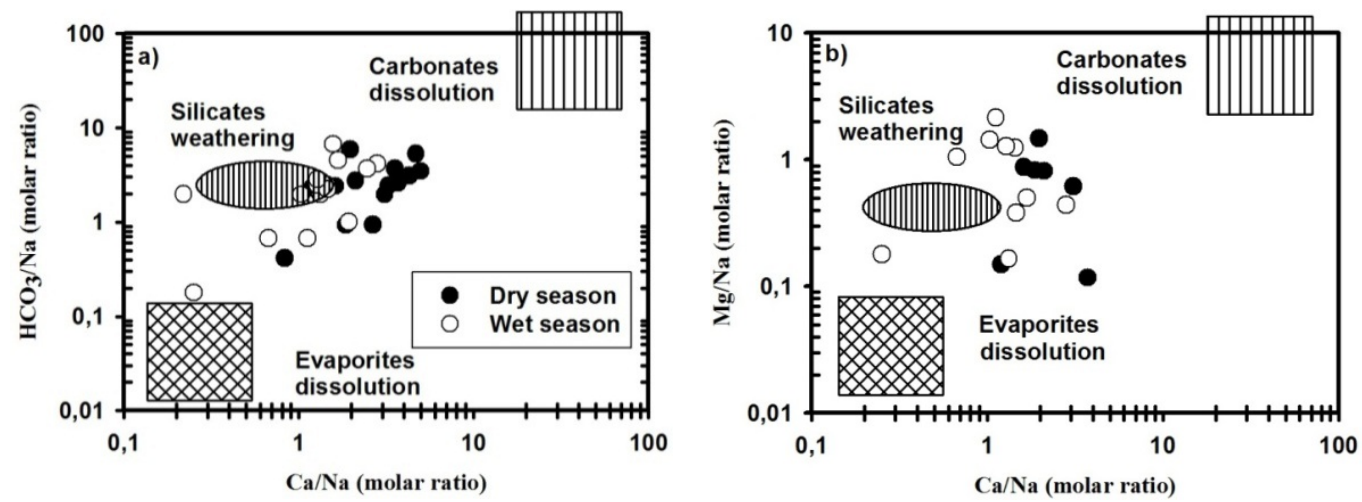

Figure 8. Bivariate plots of $\mathrm{Na}^{+}$-normalized $\mathrm{Ca}^{2+}$ versus $\mathrm{Mg}^{2+}$ and $\mathrm{Ca}^{2+}$ versus $\mathrm{HCO}_{3}{ }^{-}$. The shaded areas represent the average compositions of the waters with respect to evaporite, silicate and carbonate end-members (After

Gaillardet et al., 1999)

A close examination of the scatter plot of $\mathrm{Na} / \mathrm{Cl}$ molar ratio versus of $\mathrm{EC}$ of the samples suggests that in addition to silicate weathering, evaporation could be responsible of the major ion abundance in the dug well water. That 
is, a sample with $\mathrm{Na} / \mathrm{Cl}=1$ indicates that $\mathrm{Na}^{+}$and $\mathrm{Cl}^{-}$content in the sample is solely derived from halite dissolution, whereas a ratio $>1$ indicates that $\mathrm{Na}^{+}$was mainly derived from silicate weathering (Hem, 1985; Meybeck, 1987). On the scatter plot (Figure 9), seven samples had Na/Cl $>1$ during the wet season against four samples in the dry season, suggesting the influence of silicate weathering on the water chemistry in the wet season.

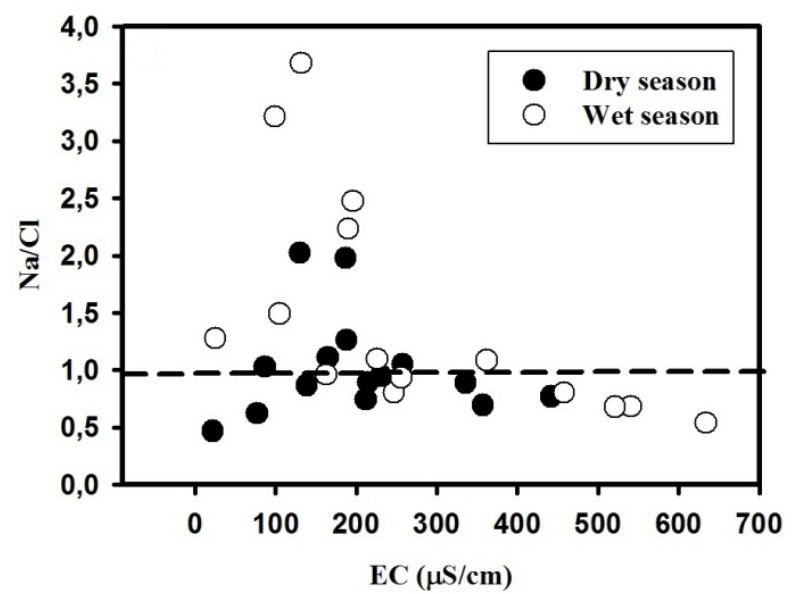

Figure 9. Relationship between $\mathrm{Na} / \mathrm{Cl}$ ratio and $\mathrm{EC}$ in dug well water, indicating the influence of evaporation process and silicate weathering on dug well hydrochemistry

Furthermore, some dry season samples were plotted in horizontal line parallel to x-axis, indicating that evaporation process partially controlled the ion abundance in the dug well water (Jankowski and Acworth, 1997; Reddy et al., 2010). Thus, evaporation process increases the concentrations of ions in well water during the dry period, whereas the water is diluted during the subsequent wet season recharge.

\section{Conclusions}

Interpretation of seasonal hydrochemical data revealed that dug well water quality in the Passakongo village is mainly controlled by both geogenic and anthropogenic processes. Although the field data showed that major ion concentrations were within the $\mathrm{WHO}$ acceptable limits for drinking water, the wells appeared to be vulnerable to $\mathrm{NO}_{3}{ }^{-}$and $\mathrm{K}^{+}$contamination. Most samples had $\mathrm{Cr}_{\mathrm{T}}$ concentrations greater than the threshold value for drinking water, whereas $\mathrm{Pb}$ posed a serious environmental problem during the wet season. According to piper and bivariate diagrams, the dug well chemistry is mainly controlled by silicate weathering, cation exchange and evaporation process during the dry season. In contrast, loadings of runoff and aquifer recharge governed the well water composition and quality in the wet season. This study demonstrated that water from unprotected dug wells is, in overall, not suitable for human consumption. Hence, urgent plan for groundwater pollution control is needed in rural Burkina Faso. Dug well water should also be purified before any domestic use, particularly during the wet season.

\section{Acknowledgments}

Comments and suggestions from two anonymous reviewers have greatly improved the earlier version of the manuscript.

\section{References}

American Public Health Association A. (2012). Standard methods for the examination of water and wastewater. American Water Works Association, Washington, DC

Appelo, C. A. J., \& Postma D. (1999). Geochemistry, Groundwater and Pollution. Balkerma, Rotterdam, Netherlands.

Appelo, C. A. J., \& Postma, D. (2005). Geochemistry, groundwater and pollution (2nd ed). Balkema, Rotterdam.

Boeglin, J. L., Ndam, J. R., \& Braun, J. J. (2003). Composition of the different reservoir waters in a tropical humid area: example of the nsimi catchment (southern Cameroon). Journal of African Earth Sciences, 37, 103-110. https://doi.org/10.1016/S0899-5362(03)00041-1 
Braun, J. J., Ngoupayou, N. J. R., Viers, J., Dupre, B., Bedimo, B. J. P., Boeglin, J. L., .. Muller, J. P. (2005). Present weathering rates in a humid tropical watershed: nsimi site (south Cameroon). Geochimica et Cosmochimica Acta, 69, 357-387. https://doi.org/10.1016/j.gca.2004.06.022

Castaing, C., Billa, M., Milési, J. P., Thieblemont, D., Le Metour, J., Egal, F., \& Donzeau, M. (2003). Notice explicative de la carte géologique et minière à 1/1 000 000ème du Burkina Faso. Proj. SYSMIN 7 ACP BK 074 UE.

Courtois, N., Lachassagne, P., Wyns, R., Blanchin, R., Bougaïré, F.D., Somé, S., \& Tapsoba, A. (2010). Large-scale mapping of hard-rock aquifer properties applied to Burkina Faso. Groundwater, 48, 269-283. https ://doi.org/10.1111/j.1745-6584.2009.00620.x

Dakoure, D. (2003). Etude hydrogéologique et géochimique de la bordure sud-est du basin sédimentaire de Taoudeni (Burkina-Faso, Mali), essai de modélisation. Thèse de Doctorat, Université Pierre et Marie Curie UPMC, 222p.

Derouane, J., \& Dakoure, D. (2006). Etude hydrogéologique et modélisation mathématique du système aquifère du bassin sédimentaire de Taoudeni au Burkina Faso. Colloque international-Gestion des grands aquifères-30 mai-1er juin, Dijon, France.

Deutsch, W. J. (1997). Groundwater Geochemistry: Fundamentals and Application to Contamination. Lewis Publisher, New York 221 pp.

Eaton, E. M. (1950). Significance of carbonates in irrigation waters. Soil Science, 69, 123-133.

EEC (European Economic Communities). (1980). Richtlinic des Rates Vem., 15.71980 liber die qualitat Von Wasser fur den menschlichen Gebrauch. Amtslelatt der Europaischen gemeinschaft vom. 30-8 No. L 229, pp. 11-29.

Fetter, C. W. (1994). Applied hydrogeology (3rd ed). Macmillan College, New York, p 616.

Frappart, F., Hiernaux, P., Guichard, F., Mougin, E., Kergoat, L., Arjounin, M., Lavenu, F., Koité, M., Paturel, J. E., \& Lebel, T. (2009). Rainfall regime across the Sahel band in the Gourma region, Mali. Journal of Hydrology, 375, 128-142. https://doi.org/10.1016/j.jhydrol.2009.03.007

Gaillardet, J., Dupré, B., Louvat, P., \& Allègre, C. J. (1999). Global silicate weathering and $\mathrm{CO}_{2}$ consumption rates deduced from the chemistry of large rivers. Chemical Geology, 159, 3-30. https://doi.org/10.1016/ S0009 -2541(99)00031 -5

Gibbs, R. J. (1970). Mechanisms controlling world water chemistry. Science, 170, 1088-1090. https://doi.org/10.1126/science.170.3962.1088

Groen, J., Schuchmann, J. B., \& Geirnaert, W. (1988). The occurrence of high nitrate concentration in groundwater in villages in northwestern Burkina Faso. Journal of African Earth Sciences, 7, 999-1009. https://doi.org/10.1016/0899-5362(88)90013-9

Hem, J. D. (1985). Study and Interpretation of the Chemical Characteristics of Natural Water. U.S. Geological Survey Water-Supply Paper No. 2254.

Huneau, F., Dakouré, D., Celle-Jeanton, H., Vitvar, J., Ito, M., Traoré, S., Compaoré, N. F., Jirakova, H., \& Le Coustumer, P. (2011). Flow pattern and residence time of groundwater within the south-eastern Taoudeni sedimentary basin (Burkina Faso, Mali). Journal of Hydrology, 409, 423-439. https://doi.org/10.1016/ j.jhydr ol.2011.08.043

Jankowski, J., \& Acworth, R.I. (1997). Impact of debris-flow deposits on Hydrogeochemical processes and the development of dryland salinity in the Yass River catchment. New South Wales, Australia. Hydrogeology Journal, 5(4), 71-88. https://doi.org/10.1007/s100400050119

John De Zuane, P.E. (1997). Handbook of Drinking water quality (2nd ed.). John Wiley \& sons, INC, pp36.

Kortatsi, B.K. (2007). Hydrochemical framework of groundwater in the Ankobra Basin, Ghana. Aquatic Geochemistry, 13, 41-74. https://doi.org/10.1007/s10498-006-9006-4.

Langmuir, D. (1997). Aqueous Environ-mental Geochemistry. Prentice Hall, New Jersey, USA.

Lester, J. N., \& Birkett, J. W. (1999). Microbiology and Chemistry for Environmental Scientists and Engineers (2nd ed.). E \& FN Spon, New York, USA 
Li, P., Zhang, Y., Yang, N., Jing, L., \& Yu, P. (2016). Major ion chemistry and quality assessment of groundwater in and around a mountainous tourist town of China. Exposure and Health, 8, 239-252. https://doi.org/10.1007/s1240 3-016-0198-6

Mall, I., Diaw, M., Dieng, N. M., Madioune, H. D., Ngom, P. M., \& Faye, S. (2015). Evaluation of water resources quality in sabodala gold mining region and its surrounding area (Senegal). Journal of Water Resource and Protection, 7, 247-263. https://doi.org/10.4236/jwarp.2015.73020

MEE (Ministry of Water and the Environment). (2001). Etat des lieux des ressources en eau au Burkina Faso et de leur cadre de gestion. Ouagadougou.

Meybeck, M. (1987). Global chemical weathering of surficial rocks estimated from river dissolved leads. American Journal of Science, 287, 401-428. https:/doi.org/ 10.2475/ajs.287.5.401

Ouédraogo, C. (1998). Cartographie géologique de la région Sud-Ouest du Burkina Faso au 1/200000-synthèse géologique. AQUATER/BUMIGEB.

Oze, C., Fendorf, S., Bird, D. K., \& Coleman, G. (2004). Chromium geochemistry of serpentine soils. International Geology Review, 46, 97-126.

Pacheco, F., \& Van der Weijden, C.H. (1996). Contributions of water-rock interactions to the composition of groundwaters in areas with a sizeable anthropogenic input: a case study of the water of the Fundao area, central Portugal. Water Resource Research, 32, 3553-3570. https://doi.org/10.1029/96WR01683

Piper, A. M. (1944). A graphical procedure in the chemical interpretation of groundwater analysis. Transactions American Geophysical Union, 25, 914-928. https://doi.org/10.1029/TR025 i006p 00914

Raghunath, H. M. (1987). Groundwater. Wiley Eastern Ltd, New Delhi, p 563.

Rail, C. D. (2000). Groundwater contamination: sources and hydrology. CRC Press.

Rakotondrabe, F., Ngoupayou, J. R. N., Mfonka, Z., Rasolomanana, E. H., Abolo, A. J. N., Asone, B. L., Ako, A. A., \& Rakotondrabe, M. H. (2017). Assessment of surface water quality of bétaré-oya gold mining area (East-Cameroon). Journal of Water Resource and Protection, 9, 960-984. https:/doi.org/10.4236/jwarp. 2017.98064.

Reddy, A. G. S., Reddy, D. V., Rao, P. N., \& Prasad, K. M. (2010). Hydrogeochemical characterization of fluoride rich groundwater of Wailpalli watershed, Nalgonda District, Andhra Pradesh, India. Environmental Monitoring and Assessment, 171, 561-577. https:/doi.org/ 10.1007/s10661-009-1300-3

Saad, K., (1970). Etude hydrogéologique du sud du Mali (Niger supérieur et Bani). UNESCO Technical Report, 2258/RMS.RS/SCE, 40p.

Sadashivaiah, C., Ramakrishnaiah, C. \&, Ranganna, G. (2008). Hydrochemical analysis and evaluation of groundwater quality in Tumkur Taluk, Karnataka State, India. International Journal of Environmental Research and Public Health, 5, 158-164. http:/doi.org/10.3390/ijerph5030158.

Sako, A., Bamba, O., \& Gordio, A. (2016). Hydrogeochemical processes controlling groundwater quality around Bomboré gold mineralized zone, Central Burkina Faso. J. Journal of Geochemical Exploration, 170, 58-71. https://doi.org/10.1016/j.gexplo.2016.08.009

Sako, A., Yaro, J. M., \& Bamba, O. (2018). Impacts of hydrogeochemical processes and anthropogenic activities on groundwater quality in the Upper Precambrian Sedimentary aquifer of Northwestern Burkina Faso. Applied Water Science, 8, 1-14. https://doi.org/10.1007/s13201-018-0735-5.

Sanou, M. (1997). Low-cost shallow tube well construction in West Africa. In: Irrigation Technology Transfer in Support of Food Security (Water Reports-14). Proceedings of a sub-regional workshop. Harare, Zimbabwe, 14-17 April 1997.

Sattran, V., \& Wenmenga, U. (2002). Geology of Burkina Faso. Czech Geological Survey, Prague, 136p.

Schöeller, H. (1962). Hydrologie dynamique et chimique. Recherche, exploitation et evaluation des ressources Masson et Cie. Editions, 642 pages.

Schöeller, H. (1965). Qualitative evaluation of groundwater resources. In Methods and techniques of groundwater investigation and development (pp. 44-52). Water Resources Series No. 33, UNESCO.

Smedley, P. L., Knudsen, J., \& Maiga, D. (2007). Arsenic in groundwater from mineralized Proterozoic basement rocks of Burkina Faso. Applied Geochemistry, 22, 1074-1092. https://doi.org/10.1016/j. apgeochem.2007.01.001. 
Soumya, B. S., Sekhar, M., Riotte, J., Banerjee, A., \&, Braun, J.-J. (2013). Characterization of groundwater chemistry under the influence of lithologic and anthropogenic factors along a climatic gradient in Upper Cauvery basin, South India. Environmental Earth Sciences, 69, 2311-2335. https://doi.org/10.1007/ s12665-012-2060-X

UN. (2015). The millennium development goals report. New York: United Nations.

Utom, A. U., Odoh, B. I. \&, Egboka, B. C. (2013). Assessment of Hydrogeochemical characteristics of groundwater quality in the vicinity of Okpara coal and Obwetti fireclay mines, near Enugu town, Nigeria. Applied Water Science, 3, 271-283. https://doi.org/10.1007/s13201-013-0080-7

WHO. (2011). Guidelines for drinking-water quality (IVth ed.). World Health Organization, Geneva, p 340.

$\mathrm{Wu}$, J., \& Sun, Z. (2016). Evaluation of shallow groundwater contamination and associated human health risk in an alluvial plain impacted by agricultural and industrial activities, mid-west China. Exposure and Health, 8 , 311-329. https://doi.org/10.1007/s12403-015-0170-X

Wuana, R. A., \& Okieimen, F. E. (2011). Heavy metals in contaminated soils: a review of sources, chemistry, risks and best available strategies for remediation. International Scholarly Research Ecology, 1-21. https:/doi.org/10.5402/2011/402647

Yaméogo, S., \& Savadogo, A.N. (2002). Les Ouverages de Captage de la ville de Ouagadougou et Leur Vulnérabilité à la Pollution. In A. H. Maiga, L. S. Pereira, \& A. Musy (Eds.), Sustainable Water Resources Management: Health and Productivity.

Zhang, W. J., Jiang, F. B., \& Ou, J. F. (2011). Global pesticide consumption and pollution: with China as a focus. Proceedings of the International Academy of Ecology and Environmental Sciences, 1, $125-144$.

Zhu, G. F., Su, Y. H., \& Feng, Q. (2008). The hydrochemical characteristics and evolution of groundwater and surface water in the Heihe River Basin, northwest China. Hydrogeological Journal, 16, 167-182. https://doi.org/10.1007/s10040-007-0216-7

\section{Copyrights}

Copyright for this article is retained by the author(s), with first publication rights granted to the journal.

This is an open-access article distributed under the terms and conditions of the Creative Commons Attribution license (http://creativecommons.org/licenses/by/4.0/). 